\title{
Kajian Penetrasi dan Permeabilitas Beton Mutu Tinggi Memadat Mandiri terhadap Variasi Komposisi Metakaolin dan Superplasticizer MasterEase 3029 Kadar 1,9\% dari Berat Binder.
}

\author{
Wibowo'), Antonius Mediyanto'), Silviana Valentin ${ }^{3)}$ \\ 1) Pengajar Fakultas Teknik, Prodi Teknik Sipil, Universitas Sebelas Maret \\ 2) Pengajar Fakultas Teknik, Prodi Teknik Sipil, Universitas Sebelas Maret \\ 3) Mahasiswa Fakultas Teknik, Prodi Teknik Sipil, Universitas Sebelas Maret \\ Jl. Ir. Sutami 36A, Surakarta 57126; Telp.0271-634524. Email: ValentinSilvianaa@gmail.com
}

\begin{abstract}
Infrastructure development in the world will never stop, because infrastructure is the economic driving force for every country, so research is increasing to get the highest quality concrete. This study discusses high strength self compacting concrete with variations composition of metakaolin. In this study metakaolin is used as a substitute for cement which has an effect on increasing the quality of concrete. The purpose of this study is to determine the optimal level of metakaolin to achieve high-quality concrete solids independently and meet the requirements of aggressive waterproof concrete. The method used in this study is experimental with the parameters studied are the penetration, permeability and workability of concrete. Cylindrical concrete with a diameter of $75 \mathrm{~mm}$ and a beight of $15 \mathrm{~mm}$. Concrete testing based on SNI 03-2914-1992, SNI 03-6468-2000, EFNARC 2000 and ACI 301-729. The results showed that all the concrete produced was of high stregth concrete, with substitution of metakaolin at $17.5 \%$ can increase concrete compressive strength up to $27,5 \%$, substitution of metakaolin at a level of $15 \%$ can reduce the value of penetration depth and the coefficient of permeability of the concrete by $36 \%$ and $93 \%$. The fresh concrete test conducted to test the concrete fillingability is the slumpflow and $V$-funnel test, while the test for passingability is the L-box test.
\end{abstract}

Key words: High Strength Self Compacting Concrete, metakaolin, penetration, permeability, fillingability dan passingability.

\begin{abstract}
Abstrak
Pembangunan infrastruktur di dunia tidak akan pernah berhenti, karena infrastruktur merupakan roda penggerak ekonomi bagi setiap negara. Sebagian infrastruktur menuntut kualitas beton mutu tinggi untuk mendukung ketahanan bangunan tersebut, perbaikan untuk mendukung hal ini adalah dengan ditambahkan pozzolan. Pozzolan yang digunakan dalam penelitian ini adalah metakaolin dengan kadar 12,5\%;15\%; 17,5\%;20\% dan 22,5\%. Seiring berkembangnya inovasi beton, penggunaan beton memadat mandiri umum digunakan di kalangan pasar konstruksi. Pembuatan beton memadat madiri membutuhkan membutuhkan FAS dan Superplasticizer yang tinggi, sehingga memungkinkan akan terbantuk pori yang besar dan banyak. Pada bangunan air seperti basemen, tangki air, dinding penahan tanah dan bendungan dibutuhkan beton yang kedap air, karena masuknya air kedalam beton dapat menyebabkan korosi terhadap tulangan sehingga akan menurunkan masa layan beton. Tujuan dari penelitian ini adalah untuk mengetahui kadar maksimum metakaolin untuk mencapai beton mutu tinggi memadat mandiri dan memenuhi persyaratan beton kedap air agresif, serta pengaruh metakaolin terhadap workabilitas beton. Metode yang digunakan dalam penelitian ini adalah eksperimental dengan parameter yang dikaji adalah penetrasi, permeabilitas dan workability beton. Beton berbentuk silinder dengan diameter $75 \mathrm{~mm}$ dan tinggi $15 \mathrm{~mm}$. Pengujian beton berdasarkan SNI $03-$ 2914-1992, SNI 03-6468-2000, EFNARC 2000 dan ACI 301 - 729. Pengujian dilakukan dengan memberikan air yang bertekanan sebesar $1 \mathrm{~kg} / \mathrm{cm}^{2}$ selama $48 \mathrm{jam}, 2 \mathrm{~kg} / \mathrm{cm}^{2}$ selama $24 \mathrm{jam}$ dan $7 \mathrm{~kg} / \mathrm{cm}^{2}$ selama $48 \mathrm{jam}$. Hasil penelitian menunjukkan semua beton yang dihasilkan merupakan beton mutu tinggi. Subtitusi metakaolin pada kadar 15\% dapat menurunkan nilai kedalaman penetrasi dan koefisien permeabilitas beton berturut - turut sebesar 36\% dan 93\%. Pada pengujian beton segar, metakaolin menurunkan workability beton tetapi hasil pengujian pada beton segar masih memenuhi standar beton memadat mandiri yang ditetapkan oleh EFNARC 2000.
\end{abstract}

Kata kunci: beton mutu tinggi memadat mandiri, metakaolin, penetrasi, permeabilitas, fillingability dan passingability.

\section{PENDAHULUAN}

Pembangunan infrastruktur di dunia tidak akan pernah berhenti, karena infrastruktur adalah roda penggerak ekonomi bagi setiap negara. Pada setiap pembangunan infrastruktur diperlukan kualitas mutu beton yang ditinggi, seperti untuk bangunan bertingkat, jalan raya, maupun bangunan air. Oleh karena itu dikembangkannya beton mutu tinggi untuk memenuhi tuntutan kebutuhan tersebut.

Self Compacting Concrete (SCC) adalah beton segar yang sangat plastis dan dapat mengalir karena berat sendirinya sehingga mampu mengisi seluruh cetakan tanpa adanya bantuan alat penggetar, dengan tetap bersifat homogen, kohesif, tidak segregasi dan tidak bleeding. Keuntungan yang diperoleh dari penggunaan beton SCC adalah menurangi waktu kerja, jumlah pekerja, pemadatan dan penggetaran beton yang optimum, serta mengurangi polusi suara bagi lingkungan sekitar.

Durabilitas beton dapat dipegaruhi oleh proses atau dampak dari lingkungan sekitar (eksternal) dan antar bahan bahan penyusun dengan bahan yang tercemar baik yang berasal dari dalam beton, ataupun pada permukaan beton (interna). Salah satu masalah yang timbul untuk struktur bangunan air adalah rembesan air yang dapat masuk ke 
dalam beton. Rembesan tersebut dapat terjadi karena tegangan permukaan ataupun perbedaan tekanan air yang masuk ke dalam beton karena beton memiliki pori yang banyak dan saling berhubungan. Air yang masuk dapat menyebabkan korosi pada tulangan beton sehingga mengurangi keawetan beton dari masa layannya.

Metakolin berasal dari batuan kaolin yang telah dihaluskan dan melalui proses pemanasan pada suhu $450-900 \mathrm{oC}$, berukuran 0,5 sampai 5 micron dan banyak mengandung $\mathrm{SiO} 2$ dan Al2O3 yang merupakan unsur utama semen. Metakolin digunakan sebagai bahan tambah dimana senyawa silika yang berada di dalamnya akan bereaksi dengan $\mathrm{CH}$ hasil reaksi hidrasi semen dan membentuk senyawa CSH yang berperan sebagai pengikat. Dengan ukuran dan sifat metakolin tersebut diharapkan metakolin dapat mengisi rongga yang terdapat pada beton, memperkecil permeabilitas dan meningkatkan kepadatan beton sehingga dapat meningkatkan kualitas dan mutu beton.

Semakin banyak penggunaan metakaolin akan menurunkan workabilitas beton segar. Hal ini disebabkan karena luas permukaan metakaolin yang lebih besar dari pada semen. Salah satu pengupayaannya adalah dengan menambahkan superplasticizer dan penggunaan faktor air semen yang tepat. Faktor air semen yang digunakan juga akan mempengaruhi pori - pori beton dan workability beton segarnya. Semakin tinggi faktor air semen akan menyebabkan kuat tekan menurun, meningkatkan kedalaman penetrasi, permeabilitas semakin tinggi dan workabilitas beton meningkat. Hal ini dapat dipahami karena semakin banyak air tersisa yang tidak digunakan saat proses hidrasi semen akan memberikan pori - pori yang besar pada beton. Maka dari itu, diperlukan pengkajian yang lebih dalam lagi untuk menentukan kadar optimum penggunaan metakaolin, serta proporsi dalam rancang campur beton untuk mendapatkan beton bermutu tinggi dan dapat memadat sendiri yang kedap air.

Beton mutu tinggi adalah suatu bahan yang dibuat dari campuran beton yaitu semen, agregat, air dan penambahan zat aditif sesuai dengan perbandingan yang sedemikian rupa sehingga campuran tersebut dapat membentuk beton yang bermutu tinggi. Menurut SNI 03-6468 - 2000 beton mutu tinggi merupakan beton yang memiliki kekuatan lebih besar sama dengan 41,4 MPa.

Beton dengan agregat normal, kekedapannya tergantung pada porositas pasta semen (A.M. Neville dan J. J. Brooks, 1987 : 264). Pasta semen yang mengeras merupakan struktur yang berpori (Kardiyono, 1996). Beton mempunyai kecenderungan berisi rongga akibat adanya gelembung - gelembung udara yang terbentuk lama atau setelah percetakan (Murdock and Book ,1999) sehingga beton tidak dapat kedap air dengan sempurna.

Pozzolan adalah bahan alam atau buatan yang terdiri dari unsur-unsur silikat dan aluminar yang reaktif. Pozzolan sendiri tidak memiliki sifat semen, tetapi dalam partikel halus bereaksi dengan air dan kapur padam pada suhu normal $\left(24-27^{\circ} \mathrm{C}\right)$ menjadi suatu partikel padat yang tidak larut dalam air (Tjoktrodimuljo,2007).

Claudia (2018) dalam penelitiannya melakukan penambahan metakaolin dengan variasi persentase $0 \% ; 12,5 \%$; $17,5 \% ; 22,5 \%$; dan $27,5 \%$ dari berat semen, menghasilkan kuat tekan berturut - turut 47,66 $\mathrm{MPa} ; 68,90 \mathrm{MPa}$; 71,33 $\mathrm{MPa} ; 54,80 \mathrm{MPa} ; 49,68 \mathrm{MPa}$ dengan menggunakan faktor air semen sebesar 0,27 dari berat binder dan superplastisizer $1,7 \%$ dari berat binder.

M.Narmatha dan T.Felixkala (2016) dalam penelitiannya menyimpulkan setelah berumur 28 hari, kuat tekan beton dengan subtitusi kadar metakaolin sebesar 5\%;10\% dan 15\% dari berat semen beruturut - turut menaikan kuat tekan beton sebesar 4,36\% ; $13,73 \% ; 17,45 \%$ dan turun pada kadar metakaolin $20 \%$ sebesar $4,26 \%$. Sehingga subtitusi kadar metakaolin sebesar $15 \%$ dari berat semen adalah kadar terbaik untuk menaikan kuat tekannya.

Ada 3 cara mekanisme transportasi air yang dapat beroperasi pada media semi- permeable seperti juga pada beton (Jackson dan Dhir, 1996), yaitu :

1. Absorbsi (penyerapan) adalah proses masuknya air/cairan melalui pori - pori atau kapiler yang terdapat pada beton. Aliran zat cair ini masuk disebabkan oleh tegangan permukaan.

2. Permeabilitas adalah proses masuknya cairan ke dalam beton karena adanya perbedaan tekanan baik cairan maupun gas. Contohnya terjadi pada bangunan penahan air, bendungan atau bangunan di dalam air.

3. Difusi terjadi karena adanya perbedaan konsentrasi baik cairan, ion ataupun gas. Perbedaan konsentrasi bahan fluida membuat transport terjadi daeri media tinggi ke media rendah.

Berdasarkan SNI 03-2914-1992, beton kedap air adalah beton yang tidak tembus air dan harus memenuhi ketentuan minimum untuk beton kedap air agresif, apabila diuji dengan cara tekanan air maka tembusnya air ke dalam beton tidak melampaui batas untuk agresif sedang tidak lebih dari $50 \mathrm{~mm}$ dan untuk agresif kuat tidak lebih dari $30 \mathrm{~mm}$.

Beton yang baik adalah beton yang memiliki permeabilitas yang rendah. Akan tetapi menurut (Murdock 1979) beton tidak dapat kedap air secara sempurna. Terbentuknya rongga / pori pada beton terbentuk dari air yang digunakan untuk proses hidrasi semen. Semakin banyak digunakan air maka semakin tinggi pula permeabilitas beton. Oleh karena itu, dalam pembuatan beton kedap air disyaratkan supaya menggunakan faktor air semen yang rendah. Berdasarkan ACI 301-729 (revisi 1975) (dalam Neville dan Brooks,1987) nilai koefisien permeabilitas maksimum pada beton disyaratkan 1,5.10-11 m/s. 
Berdasarkan EFNARC 2002 standar penelitian pengujian beton segar untuk karakteristik SCC yang memiliki parameter fillingability yang dilakukan dengan uji slumpflow dengan abrams cone dengan diameter rerata berada diantara $650-800 \mathrm{~mm}$, dengan uji $\mathrm{T}_{500 \mathrm{~mm}}$ slumpflow waktu alir berada diantara 2 detik sampai 5 detik, dengan uji $V_{\text {-funnel }}$ waktu alir harus berada diantara 6 detik sampai 12 detik. Sedangkan untuk pengujian parameter passingability dengan uji $L-B o x$ nilai perbandingan $\mathrm{h} 2$ dengan $\mathrm{h} 1$ harus berada diantara $0,8-1$.

\section{METODE}

Penelitian ini menggunakan metode eksperimental untuk mengkaji penetrasi, permeabilitas dan workabilitas (filling ability dan passingability) beton mutu tinggi memadat mandiri terhadap variasi komposisi metakaolin sebagai bahan pengganti semen. Penetrasi dan permeabilitas beton diuji pada umur beton 28 hari.

Benda uji yang digunakan dalam penelitian ini adalah silinder berdiamter $75 \mathrm{~mm}$ dan tinggi $150 \mathrm{~mm}$ sebanyak 18 silinder. Material yang digunakan adalah air, semen tipe 1, pasir, keriil, superplasticizer dan metakaolin. Alat yang digunakan adalah satu set timbangan, mix concrete, oven, pipa pvc untuk cetakan beton, kerucut abrams, papan alir dan $V$-funnel untuk pengujian fillingabilty, $L$ - box untuk pengujian passingability, dua set alat yang terdapat pada Laboratorium Bahan Universitas Sebelas Maret untuk pengujian kedalaman penetrasi dan permeabilitas beton terdapat pada Gambar 1 dan Gambar 2 dan Universal Testing Mechine untuk membelah beton.

Pengujian bahan penyusun beton yang dilakukan untuk pengujian pasir adalah uji kadar lumpur, specific gravity, pengujian kandungan organik dan gradasi agregat halus. Sedangkan pengujian pada kerikil meliputi uji gradasi agregat kasar, abrasi atau keausan dan spesivic gravity.

Metakaolin yang digunakan berasal dari batuan kaolin yang dihaluskan berasal dari desa Semin, Gunung Kidul, Yogyakarta yang kemudian dibakar pada suhu 700 derajat celcius selama 7 jam di Fakultas Seni Rupa dan Desain Universitas Sebelas Maret.

Penelitian ini merancang mix desain yang mengacu pada EFNARC 2005, SNI 03-2914-1992, SNI 03-6468-2000 dan penelitian sebelumnya Claudia Hidayat 2018 dan M.Narmatha dan T.Felixkala 2018 untuk mencapai beton mutu tinggi memadat mandiri yang kedap air.

Faktor air semen yang digunakan adalah 0,31 dengan superplasticizer BASF MasterEase 3029 sebanyak 1,9\% dari berat semen. Metakaolin yang disubtitusikan sebesar 12,5\%;15\%;17,5\%;20\% dan 22,5\% serta beton $0 \%$ sebagai beton pembanding. Rekapitulasi mix design beton dapat dilihat pada Tabel 1.

Tabel 1. Rekapitulasi Mix Desain Beton

\begin{tabular}{lcccccc}
\hline Benda Uji & $\begin{array}{c}\text { Agg Halus } \\
\left(\mathrm{kg} / \mathrm{m}^{3}\right)\end{array}$ & $\begin{array}{c}\text { Agg. Kasar } \\
\left(\mathrm{kg} / \mathrm{m}^{3}\right)\end{array}$ & $\begin{array}{c}\text { Semen } \\
\left(\mathrm{kg} / \mathrm{m}^{3}\right)\end{array}$ & $\begin{array}{c}\text { Metakaolin } \\
\left(\mathrm{kg} / \mathrm{m}^{3}\right)\end{array}$ & $\begin{array}{c}\text { Superplasticizer } \\
\left(\mathrm{kg} / \mathrm{m}^{3}\right)\end{array}$ & $\begin{array}{c}\text { Air } \\
\left(\mathrm{kg} / \mathrm{m}^{3}\right)\end{array}$ \\
\hline HSSCC MK-0\% & 821,98 & 802,67 & 600,00 & 0 & 11,40 & 186,00 \\
\hline HSSCC MK-12,5\% & 815,96 & 796,80 & 525,00 & 75,00 & 11,40 & 186,00 \\
\hline HSSCC MK-15\% & 814,76 & 795,62 & 510,00 & 90,00 & 11,40 & 186,00 \\
\hline HSSCC MK-17,5\% & 813,55 & 794,45 & 495,00 & 105,00 & 11,40 & 186,00 \\
\hline HSSCC MK-20\% & 813,28 & 793,27 & 480,00 & 120,00 & 11,40 & 186,00 \\
\hline HSSCC MK-22,5\% & 812,07 & 792,09 & 465,00 & 135,00 & 11,40 & 186,00 \\
\hline
\end{tabular}

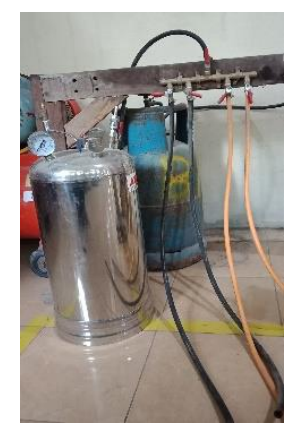

Gambar 1 Alat Uji Kedalaman Penetrasi Beton

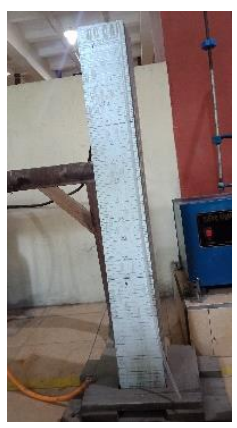

Gambar 2 Alat Uji Permeabilitas Beton

Cetakan dilepas setelah 48 jam kemudian benda uji dicuring selama 21 hari. Setelah 21 hari beda uji diangin anginkan sebelum diuji pada umur 28 hari. Setelah berumur 28 hari dan reaksi hidrasi semen selesai benda uji dikeringkan untuk mencapai berat kering oven pada suhu $100^{\circ} \mathrm{C}$ selama 24 jam. Dilanjutkan dengan memasang selang air bertekanan pada permukaan atas benda uji dengan cara memberi lubang sebesar pipa selangnya. Pipa selang yang berisi air di - sealed dan diklem pada atas permukaan beton. Benda uji yang telah terpasang diberi air dengan tekanan $1 \mathrm{~kg} / \mathrm{cm} 2$ selama $48 \mathrm{jam}, 3 \mathrm{~kg} / \mathrm{cm} 2$ selama $24 \mathrm{jam}, 7 \mathrm{~kg} / \mathrm{cm} 2$ selama $24 \mathrm{jam}$. 
Dalam penelitian ini untuk memperoleh nilai koefisien permeabilitas beton dilakukan uji penurunan air pada pipa transparan yang didiamkan selama 1 jam untuk mengetahui penurunan air. Selanjutnya membelah beton dengan universal testing mechine untuk mengukur kedalaman penetrasi beton. Nilai koefisien permeabilitas beton dapat dihitung dengan persamaan [1] berikut ini:

$$
k=\left(\frac{1}{A}\right) \cdot\left(\frac{d Q}{d t}\right) \cdot\left(\frac{L}{\Delta H}\right)
$$

\section{Keterangan:}

$$
\begin{array}{ll}
\frac{d Q}{d t} & =\text { Kecepatan aliran air } \\
\mathrm{L} & =\text { Ketebalan penetrasi pada beton } \\
\mathrm{A} & =\text { Luas penampang } \\
\Delta H & =\text { Tinggi air jatuh } \\
\mathrm{K} & =\text { Koefisien permeabilitas }
\end{array}
$$

\section{HASIL DAN PEMBAHASAN}

Berdasarkan hasil penelitian, pasir yang digunakan memenuhi standar yang ditetapkan oleh ASTM dengan nilai kadar lumpur 4,5\%, nilai specific gravity in saturated dry condition adalah 2,51 dan modulus kehalusan pasir sebesar 2,25. Sedangkan hasil uji agregat kasar juga telah memenuhi standar ASTM dengan nilai abrasi/keausan adalah 26,92\%, modulus kehalusan kerikil 7,67 dan specific gravity 2,51. Metakaolin yang digunakan mengandung $\mathrm{SiO}_{2}$ sebesar 65\% dan $\mathrm{Al}_{2} \mathrm{O}_{3}$ sebesar $15,02 \%$ yang merupakan unsur utama pembentuk semen.

Beton yang direncanakan dalam penelitian ini adalah beton normal yang memiliki berat jenis diantara $2,2 \mathrm{~kg} / \mathrm{m}^{3}$ sampai 2,5 kg/ $\mathrm{m}^{3}$ berdasarkan SNI 03-2847-2000. Salah satu pengujian beton segar untuk memenuhi standar beton memadat mandiri yang telah ditetapkan oleh EFNARC 2000 adalah dengan pengujian fillingability meliputi uji slumpflow dan $V$-funnel, pengujian parameter passingability meliputi uji $L$-box. Hasil pengujian pada beton segar dapat dilihat pada Tabel 2 berikut ini:

Tabel 2. Hasil Pengujian Parameter Beton Segar.

\begin{tabular}{lcccc}
\hline Benda Uji & $\begin{array}{c}\text { Drerata } \\
(\mathrm{mm})\end{array}$ & $\begin{array}{c}\mathrm{T}_{500 \mathrm{rerata}} \\
(\text { detik })\end{array}$ & $\begin{array}{c}\text { V-funnel } \\
(\text { detik })\end{array}$ & $\begin{array}{c}\text { L-Box } \\
(\mathrm{h} 2 / \mathrm{h} 1)\end{array}$ \\
\hline HSSCC MK-0\% & 755 & 2,21 & 10,31 & 0,947 \\
\hline HSSCC MK-12,5\% & 750 & 2,53 & 10,51 & 0,944 \\
\hline HSSCC MK-15\% & 742,5 & 2,73 & 11,27 & 0,944 \\
\hline HSSCC MK-17,5\% & 740 & 2,89 & 12 & 0,941 \\
\hline HSSCC MK-20\% & 735 & 3,14 & 12,26 & 0,842 \\
\hline HSSCC MK-22,5\% & 715 & 3,47 & 14 & 0,842 \\
\hline
\end{tabular}

Tabel 2 menunjukkan semua hasil pengujian beton segar memenuhi standar EFNARC 2000. Pada pengujian slumpflow, semua nilai diameter rerata masih berada pada nilai antara $650-800 \mathrm{~mm}$ dan waktu alir untuk menyentuh diameter sebaran $500 \mathrm{~mm}$ masih berada antara $2-5$ detik. Semua kadar memiliki nilai perbandingan $\mathrm{h}_{2}$ dengan $\mathrm{h}_{1}$ pada pengujian L-box masih bernilai diantara 0,8-1 yang berarti beton tersebut masih memenuhi persyataran beton memadat mandiri berdasarkan pengujian slumpflow dan L-box. Pada pengujian v-funnel pada subtitusi kadar $20 \&$ dan $22,5 \%$ waktu alir sudah melampaui 12 detik yang berarti beton segar sudah tidak memenuhi persyaratan beton memadat mandiri yang ditetapkan oleh EFNARC 2005 pada parameter fillingability.

Berdasarkan hasil penelitian yang diperoleh pada Tabel 2 dapat dilihat bahwa semakin tinggi kadar metakaolin yang ditambahkan akan membuat beton segar menjadi lebih kental dan menurunkan workability beton. Hal ini terjadi karena metakaolin bersifat seperti lempung yang lebih mudah untuk menyerap air dari pada semen.

Pengujian beton kedap air dilakukan dengan pengujian penetrasi dan permeabilitas beton yang mengacu pada standar yang ditetapkan oleh SNI 03-2914-1992. Hasil penelitian pada uji penetrasi dan permeabilitas dapat dilihat pada Tabel 3 berikut ini: 
Tabel 3 Hasil Rerata Pengujian Penetrasi dan Permeabilitas Beton.

\begin{tabular}{lcc}
\hline Benda Uji & $\begin{array}{c}\text { Rerata Kedalaman } \\
\text { Penetrasi } \\
(\mathrm{cm})\end{array}$ & $\begin{array}{c}\text { Permeabilitas Beton } \\
(\mathrm{m} / \mathrm{dt})\end{array}$ \\
\hline HSSCC MK-0 $\%$ & 3,2 & $3,691 \times 10^{-9}$ \\
\hline HSSCC MK-12,5\% & 2,86 & $1,411 \times 10^{-9}$ \\
\hline HSSCC MK-15\% $\%$ & 2,35 & $2,549 \times 10^{-10}$ \\
\hline HSSCC MK-17,5\% & 2,42 & $5,346 \times 10^{-10}$ \\
\hline HSSCC MK-20\% $\%$ & 2,68 & $1,335 \times 10^{-9}$ \\
\hline HSSCC MK-22,5\% & 2,85 & $1,542 \times 10^{-9}$ \\
\hline
\end{tabular}

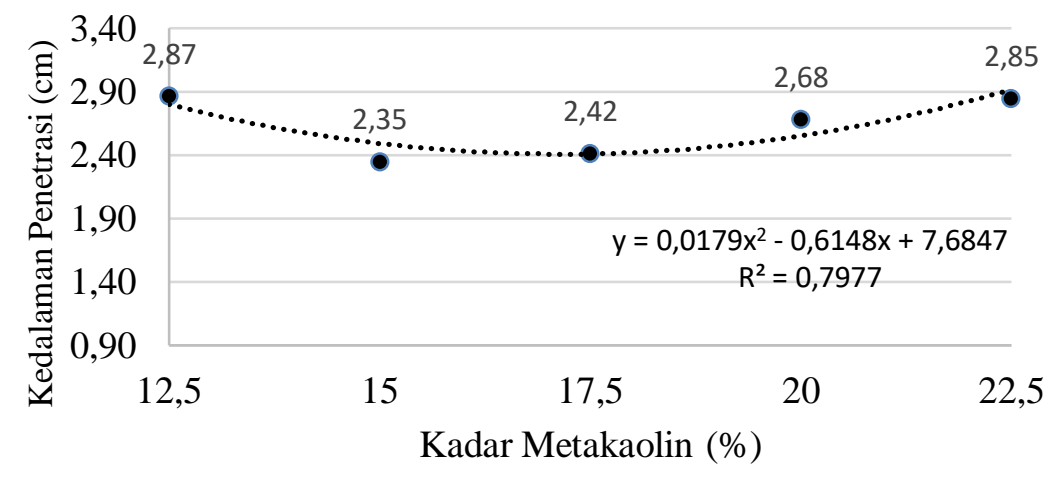

Gambar 3 Grafik Hubungan Kedalaman Penetrasi dengan Variasi Komposisi Metakaolin

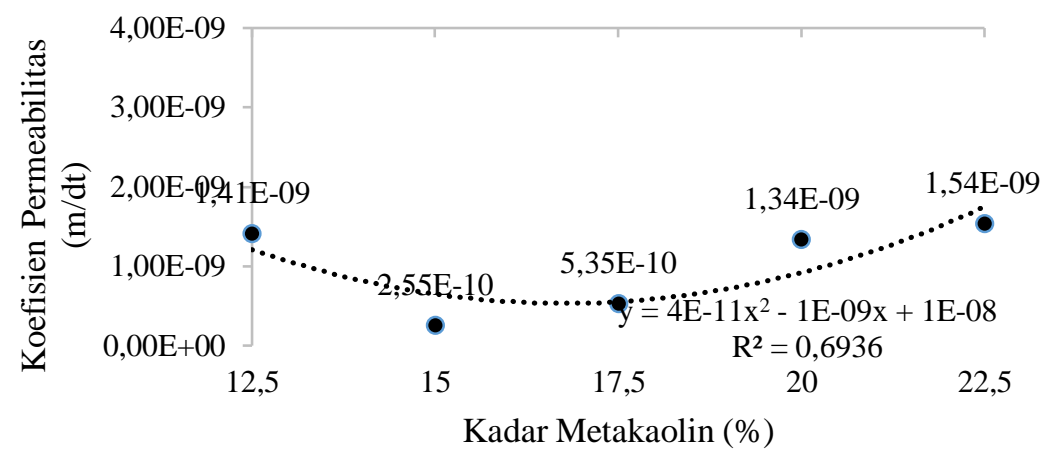

Gambar 4 Grafik Nilai Koefisien Permeabilitas Beton dengan Variasi Komposisi Metakaolin

Berdasarkan hasil penelitian pada Tabel 3 diatas menunjukan semua nilai penetrasi memenuhi syarat sebagai beton kedap air agresif yang ditetapkan oleh SNI 03-2914-1992 yaitu kedalaman penetrasi tidak lebih dari 30 mm untuk syarat agresif sedang dan tidak lebih dari $50 \mathrm{~mm}$ untuk syarat agresif kuat.

Berdasarkan hasil penelitian pada Tabel 3 diperoleh nilai subtitusi semen dengan metakaolin terbaik untuk menurunkan kedalaman penetrasi beton adalah pada 15\%. Pada beton normal tanpa metakaolin kedalaman penetrasi mencapai hingga 3,2 cm. dimana dengan mensubtitusikan semen dengan metakaolin dengan kadar 12,5\%; $15 \% ; 17,5 \% ; 20 \%$ dan $22,5 \%$ berturut - turut akan menurunkan kedalaman penetrasi sebesar $11,62 \% ; 36,17 \%$; $32,40 \% ; 19,27 \%$ dan $12,28 \%$. Berdasarkan penghitungan dengan persamaan regresi linear yang terdapat pada Gambar 3 diperoleh kadar maksimum yang dapat digunakan untuk memperoleh nilai penetrasi terkecil adalah dengan mensubtitusi semen dengan metakaolin sebesar $17,17 \%$.

Berdasarkan hasil penelitian pada Tabel 3 diperoleh nilai subtitusi semen dengan metakaolin terbaik untuk menurunkan koefisien permeabilitas beton adalah pada 15\%. Penghitungan dengan persamaan yang terdapat pada 
grafik pada Gambar 4 menunjukkan, kadar maksimum yang dapat digunakan untuk memperoleh koefisien permeabilitas terkecil adalah pada kadar 12,5\%. Berdasarkan hasil penelitian yang terdapat pada Tabel 3 menghasilkan beton normal tanpa metakaolin rerata koefisien permeabilitas beton adalah sebesar 3,691 $x 10^{-9}$ dimana dengan mensubtitusikan semen dengan metakaolin dengan kadar 12,5\%;15\%;17,5\%;20\% dan 22,5\% berturut - turut akan menurunkan koefisien permeabilitas beton sebesar $61,76 \% ; 93,09 \% ; 85,51 \% ; 63,82 \%$ dan $58,21 \%$.

Berdasarkan hukum Darcy koefisien permeabilitas dipengaruhi oleh beberapa faktor diantaranya adalah viskositas cariran yang semakin tingggi akan memiliki nilai koefisien permeabilitas yang semakin kecil, semakin kecil distribusi ukuran pori maka nilai koefisien permeabilitas akan semakin kecil, distribusi ukuran agregat yang semakin merata maka nilai koefisien permeabilitas akan semakin kecil, rasio kekosongan (void) yang semakin besar maka nilai koefisien permeabilitas akan semakin besar pula.

Tabel 3 diatas menunjukan semua koefisien permeabilitas tidak memenuhi syarat sebagai beton kedap air normal yang ditetapkan oleh ACI 301 - 729 yaitu lebih besar dari 1,5 x 10-11 m/dt. Nilai permeabilitas yang tinggi disebabkan karena lebih banyaknya pori - pori yang saling berhubungan yang terkandung dalam beton. Dalam penelitian ini nilai yang dihasilkan pada uji permeabilitas sudah berbanding lurus dengan uji penetrasi. Metode yag dilakukan sudah sesuai dengan standar yang ditetapkan, tetapi akurasi alat uji yang terdapat pada Laboratorium Bahan Universitas Sebelas Maret Surakarta kurang mendukung untuk mendapatkan hasil yang lebih valid untuk memenuhi syarat yang ditetapkan oleh ACI $301-729$.

$$
\begin{aligned}
& \mathrm{C} 3 \mathrm{~S}, \mathrm{C} 2 \mathrm{~S}+\mathrm{H} 2 \mathrm{O} \quad=>\text { C-S-H }+\mathrm{Ca}(\mathrm{OH}) 2 \\
& \text { Semen } \quad+\text { Air } \quad=>\text { kalsium silikat hidrat }+ \text { kalsium hidroksida } \\
& \mathrm{CA}(\mathrm{OH}) 2+\mathrm{Al} 2 \mathrm{O} 3.2 \mathrm{SiO} 2=>\text { C-S-H }+ \text { C2ASH8, C4AH13, C3AH6 } \\
& \text { Kalsium hidroksida }+ \text { Metakaolin }=>\text { kalsium silikat hidrat }+ \text { Kristal }
\end{aligned}
$$

Menurut Sanjay N. Patil, Anil K Gupta dan Subhash S.D (2011) reaksi pozzolanik pada metakaolin mengubah $\mathrm{Ca}(\mathrm{OH})_{2}$ menjadi C-S-H tambahan yang dapat meningkatkan kekuatan tekan dan daya rekat antara agregat yang terkandung dalam beton melalui reaksi kimia. Metakaolin mengurangi ukuran pori-pori dalam pasta semen dan mengubah banyak partikel yang lebih halus menjadi pori-pori yang tidak bersambung, sehingga mengurangi permeabilitas beton secara substansial. Dari pernyataan tersebut dapat disimpulkan menurunnya nilai kedalaman penetrasi dan koefisien permeabilitas beton terjadi karena reaksi pozzolanik mengubah $\mathrm{Ca}(\mathrm{OH})_{2}$ menjadi C-S-H yang mampu meningkatkan daya rekat yang besar antara agregat yang terkandung dalam beton. Daya rekat yang tinggi akan lebih mampu memampatkan antar rongga yang terdapat pada beton. Selain itu, senyawa C-S-H yang terjadi akibat penambahan metakaolin akan mampu mengisi rongga beton (Filler Effect). Kondisi rongga yang semakin mengecil atau zona interfasial yang semakin mengecil dan tertutupnya interkoneksitas antara rongga atau zona interfasial, akan menyebabkan terjadi deperkolasi yang memutuskan hubungan antara pori dan zona interfasial. Jumlah pori yang tertutup semakin banyak maka akan semakin sedikit air yang dapat masuk dan terjebak didalam beton.

Penurunan nilai penetrasi dan koefisien permeabilitas pada kadar 20\% dan 22,5\% terjadi akibat penambahan metakaolin yang melebihi batas optimumnya sebagai pengganti sebagian berat semen. Terlalu banyak metakaolin yang digunakan dapat diartikan terjadi penurunan persentase semen sebagai pengikat utama dalam campuran beton, sehingga reaksi antara metakaolin dengan reaksi hidrasi semen belum terjadi secara optimal.

\section{SIMPULAN}

Berdasarkan hasil pengujian, pengolahan data, dan evaluasi yang telah dilakukan, kajian penetrasi dan permeabilitas beton mutu tinggi memadat mandiri dengan variasi komposisi metakaolin dapat disimpulkan sebagai berikut:

1. Penambahan variasi metakaolin menurunkan nilai kedalaman penetrasi dan koefisien permeabilitas beton. kadar optimum yang dapat digunakan untuk memperoleh nilai penetrasi terkecil adalah pada kadar $15 \%$. Hasil nilai kedalaman penetrasi yang diperoleh dengan mensubtikan metakaolin akan menghasilkan beton yang memenuhi syarat beton kedap air yang ditetapkan oleh SNI 03-2914-1992 yaitu kedalaman penetrasi tidak lebih dari $30 \mathrm{~mm}$ untuk syarat agresif sedang dan tidak lebih dari $50 \mathrm{~mm}$ untuk syarat agresif kuat.

2. Semua koefisien permeabilitas tidak memenuhi syarat sebagai beton kedap air normal yang ditetapkan oleh ACI 301 - 729 yaitu lebih besar dari 1,5 x 10-11 m/dt. kadar optimum yang dapat digunakan untuk memperoleh koefisien permeabilitas terkecil adalah pada kadar 15\%.

3. Penambahan variasi metakaolin pada campuran beton mutu tinggi memadat mandiri menurunkan workability beton pada pengujian Slumpflow, $V$-funnel dan L-box seiring dengan bertambahnya metakaolin yang disubtitusikan, tetapi dalam penelitian ini semua pada semua penambahan metakaolin masih memenuhi syarat beton memadat mandiri yang ditetapkan oleh EFNARC 2000. 


\section{REKOMENDASI}

1. Untuk mencapai tujuan penelitian yang diharapkan, penelitian selanjutnya disarankan membuat benda uji lebih dari yang diperlukan sehingga hasil yang didapatkan lebih akurat.

2. Perlu adanya pengawasan yang ketat pada saat pemasangan alat uji penetrasi dan permeabilitas beton untuk menghindari terjadinya kebocoran pada alat sehingga air bertekanan tetap konstan. 


\section{REFERENSI}

Anonim.1983. ACI 301-729 Specifications for Structural Concrete for Buildings.

Anonim. 1992. SNI 03-2914-1992 Spesifikasi Beton Bertulang Kedap Air. Badan Standardisasi Nasional, Jakarta. Anonim. 2000. SNI 03-6468-2000 Tata Cara Perencanaan Campuran Tinggi Dengan Semen Portland Dengan Abu Terbang. Badan Standardisasi Nasional, Jakarta.

Anonim. 2002 . EFNARC 2002 Specification and Guidelines For Self-Compacting Concrete.

Anonim. 2005. EFNARC. 2005 Specification and Guidelines For Self-Compacting Concrete.

Hidayat, Claudia. 2018. Kajian Kuat Tekan Beton Mutu Tingoi Memadat Mandiri Dengan Variasi Komposisi Metakaolin dan Faktor Air Semen. Universitas Negeri Sebelas Maret, Surakarta.

Neville, A.M. 1987. Concrete Technology. Longman Scientific Technical, New York.

Namartha, et al. 2016. Metakaolin - The Best Material for Replacement of Cement in Concrete. IOSR-JMCE, India.

Patil, S.N., Gupta,A.K., Deshpande, S., 2016, Metakaolin - Pozzolanic Material For Cement in High Strength Concrete, IOSR-JMCE, India. 